\title{
Spontaneous disenclavation of phakic intraocular iris claw lens
}

\author{
Srikanta Kumar Padhy, ${ }^{1}$ Sohini Mandal ${ }^{2}$
}

'Department of Ophthalmology, Dr Rajendra Prasad Centre for Ophthalmic Sciences, AllMS, Delhi, New Delhi, India ${ }^{2}$ Department of Ophthalmology, Dr Rajendra Prasad Center for Ophthalmic Sciences, AllMS, Delhi, New Delhi, India

\section{Correspondence to} Dr Srikanta Kumar Padhy, srikantkumar.padhy19@gmail. com

Accepted 9 July 2018

Check for updates

(c) BMJ Publishing Group Limited 2018. No commercial re-use. See rights and permissions. Published by BMJ.

To cite: Padhy SK, Mandal S. BMJ Case Rep Published Online First: [please include Day Month Year]. doi:10.1136/bcr-2018226521

\section{DESCRIPTION}

A 35 -year-old male patient came to the outpatient department with sudden onset painless diminution of vision and diplopia in RE since last 3 days. The vision was 20/200 in the RE and $20 / 20$ in the LE. The patient was a known case of myopia with history of phakic eye iris claw intraocular lens (IOL) of both eyes done 12 years back. There was no history of trauma. His best-corrected visual acuity in the right eye was $20 / 20$ with -3 DS, $-0.50 D C \times 90$ in the OD. The intraocular pressure in the OD was $13 \mathrm{~mm}$ $\mathrm{Hg}$ and $15 \mathrm{~mm} \mathrm{Hg}$ in the OS. On slit lamp examination nasal disenclavation of the iris claw lens was noted, the edge of which was bisecting the non-dilated pupillary plane. The IOL was hanging inferiorly with the optic touching the corneal endothelium inferiorly and with the other end fixed at the 9 o'clock position (figure 1). The cornea was transparent. Peripheral iridotomy was noted at the 10 o'clock position temporally. A patch of iris atrophy was noted at the site of the previous iris enclavation. Immediate IOL repositioning was planned. Re-enclavation of the IOL to the iris was done under local anaesthesia, and the IOL was fixed to a site just superior to the previous fixed site (figure 2). On postoperative day 1 the patient had a vision in the OD of 20/20, unaided.

Although post-traumatic dislocation of the IOL has largely been reported, spontaneous late disenclavation of the iris claw lens is a rare complication. A disenclavation that occurs spontaneously may be because of insufficient tissue grasping, or after significant trauma even with adequate enclavation. The disenclavation rate is higher in case of aphakic iris claw lens as compared with phakic claw lens and more in posteriorly fixated IOL than anteriorly fixated IOL. The ideal location of enclavation is the mid-peripheral iris stroma, where the IOL is virtually immobile. ${ }^{1}$ The potential complications of a dislocated IOL include endothelial touch with corneal decompensation, hyphema due to trauma to the iris or angle blood vessels, pupillary block, secondary glaucoma and iris tear, and rarely damage to the lens. ${ }^{2}$ Unlike in post-traumatic disenclavation, in spontaneous cases the morphology of iris claw haptics was found to be normal in studies. Insufficient iris stroma grasping with iris tissue sliding off the iris claw fissure is the cause which can be hypothesised in spontaneous disenclavation sites. ${ }^{3}$ Re-enclavation is a procedure for refixation of the IOL,

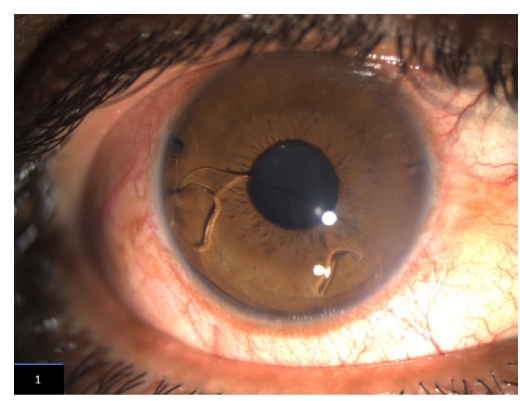

Figure 1 Slit lamp image of the RE showing inferior dislocation of the anteriorly fixed iris claw lens with nasal disenclavation.

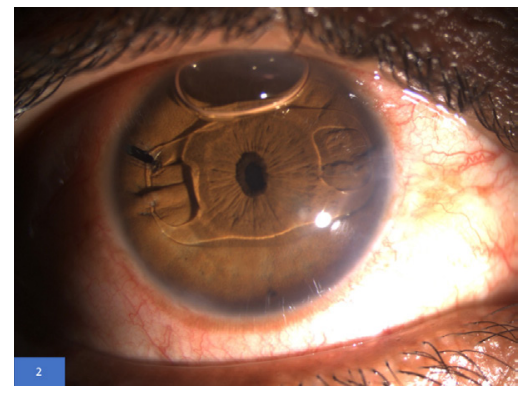

Figure 2 Slit lamp image of the RE postoperative day 1 , with the lens being re-enclavated and air bubble in the anterior chamber.

but it may be technically difficult and does not ensure against further dislocation. In cases with post-traumatic structurally damaged IOLs, IOL replacement is generally preferred. ${ }^{4}$ However, it is very difficult to predict after how much time the complication will arise.

\section{Learning points}

- Spontaneous dislocation of phakic iris claw lens is a rare but dangerous complication.

- Early management can prevent late complication and very good visual recovery.

Contributors SKP, SM: concept, design, definition of intellectual content, clinical studies, data analysis and manuscript review. SKP literature search, manuscript preparation and manuscript editing. SM: data acquisition

Funding The authors have not declared a specific grant for this research from any funding agency in the public, commercial or not-for-profit sectors

Competing interests None declared.

Patient consent Obtained. 
Images in...

Provenance and peer review Not commissioned; externally peer reviewed.

2 Shoaib KK. Posterior iris-claw aphakic intraocular lens implantation in children. Am J Ophthalmol 2013;156:849.

\section{REFERENCES}

1 Gonnermann J, Klamann MK, Maier AK, et al. Visual outcome and complications after posterior iris-claw aphakic intraocular lens implantation. J Cataract Refract Surg 2012;38:2139-43

3 Singhal S, Sridhar MS. Late spontaneous dislocation (disenclavation) of iris-claw intraocular lenses. J Cataract Refract Surg 2005;31:1441-3.

4 Brockmann T, Gonnermann J, Brockmann C, et al. Morphologic alterations on posterior iris-claw intraocular lenses after traumatic disenclavation. $\mathrm{Br} J$ Ophthalmol 2014;98:1303-7.

Copyright 2018 BMJ Publishing Group. All rights reserved. For permission to reuse any of this content visit http://group.bmj.com/group/rights-licensing/permissions.

BMJ Case Report Fellows may re-use this article for personal use and teaching without any further permission.

Become a Fellow of BMJ Case Reports today and you can:

- Submit as many cases as you like

Enjoy fast sympathetic peer review and rapid publication of accepted articles

Access all the published articles

Re-use any of the published material for personal use and teaching without further permission

For information on Institutional Fellowships contact consortiasales@bmjgroup.com

Visit casereports.bmj.com for more articles like this and to become a Fellow 